\title{
Investigation of past earthquakes in the Kopili Fault zone, NE India: New evidence of paleoliquefaction
}

\section{B.V. Lakshmi ( $\square$ lakshmi.bv@iigm.res.in )}

Indian Institute of Geomagnetism https://orcid.org/0000-0002-7224-240X

\section{Mujahed Baba}

Indian Institute of Geomagnetism

\section{Pravin B. Gawali}

Indian Institute of Geomagnetism

\section{Research Article}

Keywords: Active fault, earthquake, Kopili fault, liquefaction features, sand dyke, sand blow

Posted Date: February 18th, 2022

DOI: https://doi.org/10.21203/rs.3.rs-1349412/v1

License: (1) (1) This work is licensed under a Creative Commons Attribution 4.0 International License. Read Full License 


\section{Abstract}

The Kopili Fault (KF) zone, one of the active faults in Northeastern region (NER), has experienced large earthquakes in $1869\left(M_{w} 7.5\right)$ and $1943\left(M_{w} 7.2\right)$. In order to mitigate future occurrences of earthquakes in the KF zone it is essential to understand its long term seismic history and seismic hazard implications. Seismogenic liquefaction features were identified at three trench sites in the floodplain deposits of Kolong River, near KF zone. The liquefaction features include multiple sand dykes, sand blows and flame like intrusion. These structures are direct response to a fluid escape during liquefaction mechanism and past seismic activity. The earthquake induced liquefaction features were dated at AD 1848-1915, AD 1782-1826, AD 1640-1770, AD 1540-1626, and AD 1057-1211. The liquefaction event dated at AD 1640-1770 may correlate with the $250 \pm 50 \mathrm{yr}$ BP earthquake, recognized in an earlier study in the KF Zone, Assam. The late medieval liquefaction episodes were also identified in the study sites. The study sections also revealed sand dykes and sand blows that can be ascribed to the 1869 earthquake. The data generated in the present study deciphers five temporally close intervals of earthquakes of large types in the KF Zone during the last $\sim 1000$ years with a return period of $\sim 200$ years. Additional excavations and dating of earthquake induced liquefaction features is required to precisely evaluate the frequency of major earthquakes in the KF zone.

\section{Introduction}

One of the most useful secondary evidence in the category of seismically generated structures in the field of Paleoseismology is liquefaction. Liquefaction of saturated cohesionless sediments is caused by increase of the pore-water pressure due to the propagation of the cyclic shear waves during seismic shaking (Youd 1973; Sims 1973 Youd 1977; Seed 1979; Obermier 2009). Liquefaction is defined as transformation of a granular material from a solid to liquefied state due to increased pore-pressure. One of the main mechanisms, which produce liquefaction, is the cyclic shear stress/strain induced by earthquakes. Liquefaction occurs mostly in soft sedimentary sequences like fine and coarse sand/silt but has minor effect on sandy-gravels (Obermeier 1996; Owen and Moretti 2011). The liquefaction structures include sand dykes, sand blows, sand viens, pseudonodules, convolute bedding, load structure, diapirs, etc. The minimum earthquake magnitude able to cause liquefaction is M 5-6 (Allen, 1986; Obermeier and Pond 1999) and the factors that control the liquefaction are lithology, depth to the water table, epicentral distance, magnitude, earthquake duration, ground acceleration and amplitude of cycles (Seed, 1979; Obermeier 1996; Moretti et al., 1999). Several studies have used liquefaction features as proxies in various geological and tectonic settings to investigate the seismic history (e.g. Russ 1982; Obermeier 1998; Talwani and Cox 1985; Sims and Garvin 1995; Sukhija et al. 1999; Rajendran et al. 2004; Tuttle et al. 2006; Obermeier 2009; Tuttle et al. 2019).

The north-east region (NER) of India has experienced high-magnitude earthquakes due to the ongoing collision of the Indian Plate with the Eurasian plate to the North; and Burmese plate to the East (Ambraseys and Douglas 2004; Bilham 2004) and the continual tectonics can potentially lead to more seismic activity. Hence, comprehending the frequency of major earthquakes becomes a prerequisite by focusing at evidence of the paleoearthquakes in the tectonically active regions. In the Himalaya, Paleoseismic investigations have been carried by trenching across primary fault scarp (e.g. Anand and Jain 1987; Jayangondaperumal 
and Thakur 2008; Kumar et al. 2010; Philip et al. 2011; Malik et al. 2015; Rajendran et al. 2015; Mishra et al. 2016; Jayangondaperumal et al. 2017; Malik et al. 2017; Priyanka et al. 2017; Pandey et al. 2021; Singh et al. 2021). Paleoseismic studies using liquefaction features (Sukhija et al. 1999; Singh and Jain 2007; Jayangondaperumal et al. 2008; Binita and Sharma 2009; Reddy et al. 2009; Morino et al. 2011; Singh et al. 2020; Jayangondaperumal 2021; Rajendran 2021; Lakshmi and Gawali 2022), and the historical earthquake catalogues (Bapat et al. 1983; lyengar et al. 1999; Baro and Kumar 2017) suggested multiple seismic events to have occurred during the last millennium.

Where seismogenic faults are difficult to recognize, earthquake-induced liquefaction features have been the focus of a number of Paleoseismological studies (e.g. Amick et al. 1990; Obermeier 1998; Saucier 1989; Tuttle and Seeber 1991; Tuttle and Atkinson 2010). Several recent earthquakes, including the 1897 Shillong and the 1950 Assam, induced liquefaction but were not associated with surface rupture. These earthquakes raised the awareness that certain types of prehistoric earthquakes could not be identified by studying surface faults. Therefore liquefaction features are used increasingly in Paleoseismological investigations around the world, wherever sediments susceptible to liquefaction are present. Criteria for recognizing earthquake induced liquefaction features from other types of soft sediment deformation structures already have been described in several papers (e.g. Sims and Garvin 1995; Obermeier 1996; Tuttle et al. 2006 and reference therein). Paleoseismic investigations in the meizoseismal area of 1897 Shillong earthquake, 1950 Assam earthquake, along Kopili Fault (KF) and Dauki Fault (DF), revealed well-preserved liquefaction and deformed syndepositional features at selected sites in the alluvial deposits along the tributaries of the Brahmaputra River, Shillong plateau (SP), NER, India (Sukhija et al. 1999; Rajendran et al. 2004; Reddy et al. 2009; Kumar et al. 2016; Morino et al. 2011, 2014, Lakshmi and Gawali 2022).

Kumar et al. (2016) carried out paleoseismological studies using seismogenic liquefaction in the floodplain deposits of Kopili and Kolong Rivers. They excavated trenches at two locations and observed several sand dykes. In addition, they suggest three intervals of liquefaction formations using radiocarbon and OSL dating techniques. The paleoseismological record, however, provides only part of the data necessary to fully understand seismic hazard in the region. Observations of liquefaction features in the NER (Sukhija et al. 1999; Rajendran et al. 2004; Reddy et al. 2009) and accounts of liquefaction during historical earthquakes suggest that a history of paleoliquefaction events can be gleaned from the geologic record that would shed light on the long-term behaviour of the KF.

Here we present new evidence of sand blows and sand dykes resulted from the paleoearthquakes centered at KF region. In this paper, we communicate the outcome of study carried out mainly in River/channel cutoffs of Kolong River, Assam to investigate the liquefaction fields by excavating abandoned flood plain of Brahmaputra River and age constrains on liquefaction features using OSL dating.

\section{Seismotectonics}

The contiguous distribution and frequency of large intraplate earthquakes in India are poorly understood. The subduction of Indian plate under the Eurasian plate in the north brought Himalayan mountain ranges into picture while the eastern collision-subduction zone caused the existence of the Indo-Burma ranges 
(Fig. 1). As a result, the NER has a complex tectonic setting with a history of past large to great earthquakes (Ambraseys and Douglas 2004; Oldham 1899; Bilham 2004; Kayal 2008; Angelier and Baruah 2009). Four great earthquakes of magnitude $(M)>8.0$ in the last ca. hundred years: the 1897-Assam earthquake; 1905 Kangra earthquake; 1934 Bihar-Nepal earthquake, and 1950 upper Assam earthquake occurred in NER (Fig. 1). The $300 \mathrm{~km}$ long and $50 \mathrm{~km}$ wide $\mathrm{KF}$ is seismically very active due to its transverse tectonics which makes the region at risk for impending large earthquakes (Kayal et al. 2012). The KF which separates Shillong Plateau from the Mikir hills, is one of the most important tectonic features of the NER. The KF zone is bounded by the Himalayan collision in north, the Indo-Burmese subduction zone to the south, the syntaxis zone in the east, and the SP in the west (Fig. 1). Many devastating earthquakes occurred in the past around the KF zone viz., 1869 Cachar earthquake of $\mathrm{M}_{\mathrm{w}}-7.38$ (Oldham 1883), 1943 Hajoi earthquake of $\mathrm{M}_{\mathrm{W}}-7.24$ (Nandy and Dasgupta 1991; Nandy 2001; Ambrasesys and Douglas 2004); 1941 Tezpur earthquake of M-6.5 and 2009 Bhutan earthquake of M-6.9 (Kayal et al. 2012) (Figs. 1 and 2).

\section{Methods And Research Approach}

Sites that liquefied during large modern earthquakes and historic earthquakes furnish good target for paleoliquefaction studies because liquefaction often reoccur where susceptible sediments are present. Therefore we have carried out investigation for liquefaction features along Kolong River near Namgaon, Satargaon and Nampani near KF Zone in the eastern part of SP where ground failure and sand vents were reported during 1869 Cachhar and 1943 Hajoi earthquakes. Overbanks of the Kolong River were examined, during November and December 2016, for the liquefaction and other soft-sediment deformation structures, to assess spatiotemporal extent of strong shaking in KF zone (Figs. 3, 4, and 5). We found, and have studied, many earthquake-induced liquefaction features along Kolong River. The information from sites is gathered from local knowledge by oral communication. The methods employed for identifying earthquake induced liquefaction include reconnaissance of open ground and River/stream cut-offs, investigation of sand-blow/sand dyke features by making trenches, documentation of liquefaction features by logging and river exposures.

The strata here are susceptible to liquefaction, because the riverine sand beds with confining clay layers are better situated for increased pore pressure, under shallow water table conditions. Identification of liquefaction features in the field in Brahmaputra flood plain is not always suitable due to experience of monsoonal flooding and erosion by River during high flows. Consequently, during progressive excavation we observed liquefaction features viz., several sand dykes (Figs. 3-5) as well as multiple dykes rising from the sand reservoir, mainly along and adjoining areas of the Kolong River, a tributary of Brahmaputra and in distal parts of the alluvial fans. Samples for optically stimulated luminescence (OSL) age determinations were collected from different stratigraphic level to obtain maximum and minimum or contemporaneous ages of the liquefaction feature. As it is found that both sites have fluvial dominated deposits which hindered to trace the presence of organic samples. The samples were collected in PVC tubes of $20 \mathrm{~cm}$ long and $2.5 \mathrm{~cm}$ diameter and OSL dating was carried out by Wadia Institute of Himalayan Geology (WIHG), Dehradun (Table 1). Several studies have shown that in a given site recurring liquefaction corresponds to multiple earthquakes occurring at different time intervals (Youd 1977; Saucier 1989; Tuttle and Seeber1991; 
Obermeier 1998; Sims and Garvin 1995). The method to differentiate subsequent events of liquefaction is based on the stratigraphic criteria and cross-cutting relationships.

Table 1

Optically stimulated luminescence (OSL) ages of sediment samples(See Figs. 4, $5 \& 6$ for sample location)

\begin{tabular}{|c|c|c|c|c|c|c|c|c|c|}
\hline Lab No & $\begin{array}{l}\text { Sample } \\
\text { No/site } \\
\text { no. }\end{array}$ & Protocol & $\begin{array}{l}\text { Depth } \\
\mathrm{cm}\end{array}$ & $\begin{array}{l}K \\
(\%)\end{array}$ & $\begin{array}{l}\text { U } \\
\text { (ppm) }\end{array}$ & $\begin{array}{l}\text { Th } \\
\text { (ppm) }\end{array}$ & $\begin{array}{l}\text { Mean } \\
\text { Equivalent } \\
\text { Dose (De) } \\
\text { Gy }\end{array}$ & $\begin{array}{l}\text { Dose } \\
\text { Rate } \\
\text { (Gy/ka) }\end{array}$ & $\begin{array}{l}\text { Age } \\
\text { Age } \\
(\text { yrs) } \\
(A D)\end{array}$ \\
\hline LD3120 & $1 / \mathrm{NG} / \mathrm{SB}$ & DSAR & 130 & 1.8 & 2.71 & 17.8 & $\begin{array}{l}0.88 \pm 0.1 \\
(n=5)\end{array}$ & $\begin{array}{l}3.1 \pm \\
0.3\end{array}$ & $\begin{array}{l}286 \pm \\
39 A D \\
1692- \\
1770\end{array}$ \\
\hline LD3124 & $2 / N G$ & SAR & 100 & 1.7 & 3.13 & 14.2 & $\begin{array}{l}0.65 \pm \\
0.05(\mathrm{n}= \\
17)\end{array}$ & $\begin{array}{l}3.0 \pm \\
0.3\end{array}$ & $\begin{array}{l}213 \pm \\
22 \mathrm{AD} \\
1782- \\
1826\end{array}$ \\
\hline LD3122 & $3 / N G$ & DSAR & 80 & 2.3 & 1.38 & 23.7 & $\begin{array}{l}0.54 \pm \\
0.05 \\
(n=6)\end{array}$ & $\begin{array}{l}3.6 \pm \\
0.3\end{array}$ & $\begin{array}{l}151 \pm \\
18 \mathrm{AD} \\
1848- \\
1885\end{array}$ \\
\hline LD3123 & 4/NP/SB1 & SAR & 30 & 1.9 & 2.19 & 22.3 & $\begin{array}{l}0.38 \pm \\
0.03 \\
(n=17)\end{array}$ & $\begin{array}{l}3.3 \pm \\
0.3\end{array}$ & $\begin{array}{l}115 \pm \\
13 A D \\
1889- \\
1915\end{array}$ \\
\hline LD3125 & 5/NP/SB2 & DSAR & 82 & 1.7 & 2.78 & 17.3 & $\begin{array}{l}1.07 \pm \\
0.09(\mathrm{n}= \\
17)\end{array}$ & $\begin{array}{l}3.2 \pm \\
0.3\end{array}$ & $\begin{array}{l}339 \pm \\
38 \mathrm{AD} \\
1640- \\
1716\end{array}$ \\
\hline LD3126 & 6/NP/SB3 & DSAR & 70 & 1.9 & 1.77 & 14.4 & $\begin{array}{l}1.28 \pm \\
0.08(\mathrm{n}= \\
20)\end{array}$ & $\begin{array}{l}2.9 \pm \\
0.3\end{array}$ & $\begin{array}{l}434 \pm \\
43 \mathrm{AD} \\
1540- \\
1626\end{array}$ \\
\hline LD3121 & 7/SG/SB1 & SAR & 57 & 2.5 & 3.52 & 28.0 & $\begin{array}{l}3.9 \pm 0.13 \\
(n=26)\end{array}$ & $\begin{array}{l}4.4 \pm \\
0.4\end{array}$ & $\begin{array}{l}883 \pm \\
77 \mathrm{AD} \\
1057- \\
1211\end{array}$ \\
\hline
\end{tabular}

Optically stimulated luminescence (OSL)measurement were carried out in an automated Riso TL/DA15 reader equipped with filtered green light from a halogen lamp, which is located at theWadia Institute of Himalayan Geology, Dehra Dun, India. For the annual dose rate estimation, concentration of uranium, thorium, and potassium in the sediments were measured by XRF. The single aliquot regeneration protocol (Murray and Wintle 2000) was used for equivalent dose determination. Water content assumed: $15 \pm 5 \%$ by weight. 35 aliquots were used per samples.However, for LD3120 and 3122, 70 disc each were analyzed. For De calculation aliquots with recycling ratio within $10 \%$ were considered, $n$ represents the number of aliquots qualified the criteria and considered in ED estimation. Overdispersion for all the samples was less than 20 hence mean age model was used for paleodose estimation 


\section{Results Of Investigations}

Results of the search for and dating of liquefaction features along Kolong River, near KF region are summarized in Table 1 and illustrated on Figs. 3, 4 and 5. Along Kolong River, we found twelve liquefaction features in three trenches at three sites Namgaon (NG; Trench 1) Nampani (NP; Trench 2) and Satargaon (SG; Trench 3) (Fig. 2). Liquefaction features include sand dykes up to $23 \mathrm{~cm}$ wide and six sand blow deposits. The documented liquefaction features and their age constraints are discussed below.

\subsection{Namgaon Site}

The liquefaction features were developed in alluvial sediments and best observed at excavation area (Fig. 2). In 1.8 long and $~ 2 \mathrm{~m}$ deep trench 1 along Kolong River at Namgaon (N 26² 12'50.5"; E $\left.92^{\circ} 26^{\prime} 41.7^{\prime \prime}\right)$, five dykes (D1, D2, D3, D4 and D5) in a radial pattern and a small sand blow (SB) are observed (Fig. 3A). These dykes range from 25 to $55 \mathrm{~cm}$ height and 5 to $20 \mathrm{~cm}$ wide. Two generation of main dykes D1 and D2 indicate that they may be originating from the same source and two dyke outlets (D3 \& D4) are originating from the D1 dyke (Fig. 3B). They are composed predominately of fine to medium sand. In addition, there is a second generation of sand dyke D2 composed of fine sand that crosscuts the older D3 dyke. The stratigraphic position and crosscutting relation of D3 dyke shows that it is older than D2 dyke and clearly indicates their formation in two distinct events which might have occurred within a short period of time. The D1 dyke intruding into host silt/clay layer is seen to terminate in to the related sand blow (Fig. 3B). This sand dyke (D1) appears to be a compound feature that was utilized during repeated episodes of liquefaction. The oldest sand blow occurring in the bottom of the section $(1.3 \mathrm{~m}$ below the surface) is about $10 \mathrm{~cm}$ thick, composed of very fine sand and fed by D1 dyke. Older dykes D3 and D4 terminate in the host deposit at $110 \mathrm{~cm}$ and $95 \mathrm{~cm}$ from the ground surface and younger D2 dyke at $80 \mathrm{~cm}$ respectively. Given its stratigraphic position within the section, the D2 dyke probably resulted from the youngest earthquake. Older Dyke D5 indicate that this may be originating from different source sand and terminates at $\sim 98 \mathrm{~cm}$ in the host deposit. D3, D4 and D5 are laid approximately at the same depth. The timing of the earthquake(s) which caused the formation of these features can be found (a) by direct dating of blown out sand (from sandblow) and (b) bracketed between the age of the intruded sand and age of the capping layer. Age constraints were developed on the basis of three OSL dates: AD 1848-1885 (151 \pm 18$)$, AD 1782-1826 (213 \pm 22 years) and AD 1692-1770 (286 \pm 39 years). Among these the OSL date of AD 1692-1770 denotes the contemporaneous age for the older event (Sand blow, Fig. 3B), AD 1782-1826 provides maximum age for D2, D3 and D4 dykes and AD 1848-1885 provides maximum age for D2 dyke (Fig. 3B).

\subsection{Nampani site}

Trench 2 near Nampani village ( $26^{\circ} 21^{\prime} 58^{\prime \prime} ;$ E 92 $\left.46^{\prime} 38.7^{\prime \prime}\right)$, revealed a $3 \mathrm{~m}$ long and $2 \mathrm{~m}$ deep sedimentary section consisting of white sand layers, brown sand, and clay (Fig. 4A). Here we observed three generations of sand blows and related sand dykes. The oldest sand blow 3 (Unit 6 ) occurs low in the section and is up to $\sim 5-15 \mathrm{~cm}$ thick, composed of fine brown sand, and fed by two sand dykes, ranging from 8 to $10 \mathrm{~cm}$ in width (Fig. 4D). The sand blow immediately overlies a soil developed in clay. Dyke 2 is intruding on to the 
surface and light yellow in color and attains an height of $60 \mathrm{~cm}$ and $5 \mathrm{~cm}$ width (Fig. 4D). A younger sand blow 2 (Unit 4), occurring in the middle of the section is about 10-30 cm thick, composed of very fine sand containing a few small clasts, and of limited lateral extent and is fed by at least one sand dyke (Dyke 1) (Fig. 4C). The youngest sand blow 1 (Unit 2), occurring high in the section is only $50 \mathrm{~cm}$ thick and consists of white fine sand (Fig. 4B).

Age constraints were developed on the basis of three OSL dates within SB1, SB2 and SB3 yielded ages of

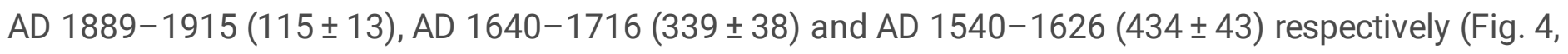
Table 1). These dates (AD 1889-1915, AD 1540-1626 and AD 1640-1716) provides contemporaneous ages for the sand blows 1,2 and 3 respectively.

\subsection{Satargaon site}

At Satargaon site ( $\mathrm{N} 26^{\circ} 23^{\prime} 12.5^{\prime \prime} ; \mathrm{E} 92^{\circ} 47^{\prime} 43.1$ ), we observed two sand blows (Sand blow 1 (SB1) and sand blow (SB2)) and a dyke $2 \mathrm{~m}$ long and $1.2 \mathrm{~m}$ deep trench (Fig. 5A). The section consists of alternate layers of clay, silt and sand. The SB2 (Unit 5) is $\sim 10 \mathrm{~cm}$ thick and SB1 is $25 \mathrm{~cm}$ thick and composed of fine silt and brown sand (Fig. 5B). One main sand dyke, $5 \mathrm{~cm}$ wide, fed the SB1. The dyke composed of fine light yellow color sand, crosscutting unit 6 and is terminated in Unit 5 (SB2). Flame like intrusion of clay deposit is also observed (Unit 4) and clasts of clay are also seen in the sand blow. Sample collected from within the sand blow 1 yielded OSL date of AD 1057-1211 (883 \pm 77 ) (Table 1). It provides contemporaneous age constraint for the event.

\section{Discussions}

\subsection{Timing, Sources and Magnitude of Paleoearthquakes}

The stratigraphic criteria, geometry and cross-cutting relations of deformational features provide evidence for repeated liquefaction events to seismic activity. The deformational features found in the present study, such as sandblows, sand dikes and flame structures, are correlated to earthquake induced mechanism because their morphology indicates sudden application of a large upward-directed hydraulic force of short duration (Obermeier 1996) and presence of clasts. Similar features were observed in different geological and tectonic regimes during strong historical earthquakes (Obermeier 1996; Tuttle and Atkinson 2010; Mugnier et al. 2011; Cox et al. 2012, 2014) and have been reported earlier from different depositional environments in India including the Brahmaputra plains of NE India (Sukhija et al. 1999; Sukhija et al. 2002; Rajendran et al. 2004; Thomas et al. 2007; Jayangondaperumal and Thakur 2008; Reddy et al. 2009; Jayangondaperumal et al. 2011; Mugneir et. al. 2011; Kumar et al., 2016; Lakshmi and Gawali 2022).

In the present study along Kolong River basin, from the structural, stratigraphic, and age relations at sites suggest that the paleoliquefaction features probably formed as the result of five earthquake events (Table 1) in a closely timed earthquake sequence including the 1869 Cachar earthquake. Previous studies demonstrates that using OSL, 'direct dating' of prehistoric earthquakes may be possible, if sand blows from liquefied dykes are preserved (Thomas et al. 2007; Porat et al. 2007). The ages obtained from present study is grouped in to five seismic events (Fig. 6). Evidence for Event I is recorded in Trenches 1 and 2 (Figs. 3 and 
4). According to the OSL ages measured at this site (Table 1), the Event I is constrained by both maximum and contemporaneous ages (Fig. 6). The maximum age (AD 1848-1885) of Event I is provided by youngest liquefaction features in Trench 1 (Fig. 3) at Namgaon site. This event is also inferred from contemporaneous age (AD 1889-1915) in trench 2 and is recorded in youngest sandblow. Evidence for Event II liquefaction which took place sometime during the period AD 1782-1826 has been recorded in Trench 1 (Fig. 6). Event III has been inferred from the age constraints of sand blow in Trench 1 (Figs. $3 \& 6$ ) at Namgaon site and Sand blow 2 in Trench 2 (Figs. 4 \& 6) at Nampani site. Two contemporaneous OSL ages AD 1692-1770 and AD 1640-1716 points to an earthquake in 17th and 18th century. Present study also provide Event IV in Trench 2 and the contemporaneous OSL age 1540-1626 points to an earthquake in the 16th and 17th century (Fig. 6). Event $V$ occurring at AD 1057-1211 is also identified from Trench 3 at Satargaon site (Fig. 6).

Instrumental records over the last five decade suggest that Cachar earthquake of 1869 (Mw-7.4) and Hajoi earthquake of 1943 (Mw 7.2) occurred in the study area which was associated with the NW-SE trending KF (Figs. 1 \& 2) (Kayal et al. 2012). These data allow us to correlate the Events I and II to one of the two large earthquake occurred in this time interval in this area: 1869 or 1943 events. As far as the age of the events is concerned, given the limited results of the dating available (Table 1) we can conclude that Events I and II may be associated to the 1869 Cachar, which is the nearest and strongest event for which historical sources report liquefaction in the area. The 1869 event occurred in the southeastern end of the KF and has been well described by Oldham (1883). It is equally possible that the AD 1943 Hajoi earthquake, on the basis of historical accounts, may have produced liquefaction if it was similar to the mechanism of 1869 earthquake. However, a little information is available for the 1943 event except newspaper report (Dasgupta 2011) which occurred farther north of 1869 event. However, there is no large event in the KF zone since the 1943 M 7.3 Hajoi earthquake. Although it is tempting to compare Event III (AD 1692-1770 and AD 16401716) with the earthquake of $A D 1697$ Sadiya, this event is unlikely to have generated liquefaction in the region, where our study sites are located due to the distance to the assumed source, However, this data support to tally the liquefaction episodes to $250 \pm 25$ year BP in the same geological conditions along KF Zone (Kumar et al., 2016). Although AD 1548 earthquake (lyengar and Sharma 1998) is the closest historical event for Event IV (AD 1540-1626) from the present study, it is hazy to correlate the two, based on one exposure of a liquefaction layer. Kumar et al. (2016) dated the liquefaction feature that occurred about 900 year BP at the Kakotigaon along Kolong River which is near by present study sites. This data suggest that the liquefaction Event $V(A D$ 1057-1211) at Satargaon site in the present study may correspond to 900 year BP, but only one age precludes this conclusion (Fig. 6). Dating of more paleoliquefaction features at additional sites in the KF would greatly improve our determination of the timing and the likely seismic source.

The contiguous spreading of liquefaction fields $(\sim 41 \mathrm{~km})$ along the Kolong River indicate local earthquakes of approximately $M>=6.0$ using empirical relation of Ambraseys (1988) for moment magnitude to distance of farthest liquefaction to epicentre. If all the liquefaction events resulted from the $\mathrm{KF}$, then according to Ambraseys (1988) the earthquakes were approximately $M-6.5$. The present study 
liquefaction fields recorded at least five local earthquakes in 1000 years, with a conjectural average recurrence interval of approximately 200 years for $M 5.5$ to 6.5 events.

In the past, the KF has experienced several earthquakes of magnitude 4.5 to 6.2 , three of magnitude 6 to 7 and two earthquakes of magnitude greater than 7 viz., 1869 Cachhar and 1943 Hajoi earthaquakes. This region has been identified as a probable region for future generating large magnitude earthquakes (Kayal et al. 2006, 2010, 2012). Recently, it is argued that KF cuts across the Himalayas and caused displacement and curvilinear structure at the Main Boundary Fault and Main Central Thrust zones (Kayal et al. 2010, 2012). Paleoseismic investigation in the KF zone by Kumar et al. (2016) revealed seismogenic liquefaction features near Kopili and Kolong Rivers which correspond to the occurrence of three ( $250 \pm 25$ year BP, between 400 and 700 year BP and $900 \pm 50$ year BP) causative seismic events. However, both the studies, Kumar et al. (2016) and present study, indicates that an earthquake of comparable magnitude occurred in the Assam, which has generated liquefaction features of similar dimensions in the source zone nearby KF zone. But there is also a possibility that even a distant great earthquake could generate liquefaction in the KF zone. The limited dating constrains based on only limited liquefaction features are presented here and are less than sufficient to develop a timeline of earthquakes that impacted the KF.

\section{Conclusions}

A wealth of information regarding paleoearthquakes is accessible in the form of seismically induced liquefaction features conserved in the alluvial deposits along Kolong River near KF region. During our paleoseismic investigation, we found eleven liquefaction features and included small to big five sand blows, eight sand dikes at sites Namgaon (NG), Nampani (NP) and Satargaon (SG). On the basis of OSL dating, we interpret that the episodic liquefaction features at the three sites formed about AD 1848-1915, AD 1781-1825, AD 1646-1769, AD 1539-1625, and AD 1056-1210. Several fault zones in the SP, including the DF, Oldham Fault, Dapsi Thrust and KF are thought to be active on the basis of their apparent influence on local topography and hydrography. The geological evidence for the five seismic events from the present study and previous studies indicates that the KF appears to be active since mid-Holocene. Additional investigations of identification of liquefaction features are required to authenticate our findings. More studies on liquefaction features would provide better constrains on timing, magnitude and sources of paleoearthqukes in the KF zone. These details in turn help in interpretation of long-term rupture history of faults and intraplate seismicity. Eventually, present study demonstrates that the paleoseismic investigations can provide useful information on past earthquakes through recognition of liquefaction features in the absence of surface rupture. Paleoseismic approach also contribute data on unknown seismic events in seismically active region like SP.

\section{Declarations}

\section{ACKNOWLEDGEMENTS}

The Authors are grateful to Director, IIG, for his support and necessary permission for publishing this paper. We acknowledge financial support from CLAIMs in house programme of DST-IIG. 
Funding This is DST-IIG funded in house CLAIMS Project

\section{Author Information}

Affiliations

\section{Indian Institute of Geomagnetism, Navi Mumbai, India}

B.V. Lakshmi, Mujahed Baba and Pravin B. Gawali

\section{Corresponding author}

Correspondence to B.V. Lakshmi

\section{Competing Interest}

The authors declare that they have no known competing financial interests or personal relationships that could have appeared to influence the work reported in this paper.

\section{References}

1. Allen JRL (1986) Earthquake magnitude-frequency, epicentral distance, and soft-sediment deformation in sedimentary basins. Sediment Geol 46(1-2):67-75

2. Ambraseys NN (1988) Engineering seismology. Earthq Eng Struct Dyn 17:1-105

3. Ambraseys NN, Douglas J (2004) Magnitude calibration of north Indian earthquakes. Geophys J Int 159:165-206

4. Amick D, Gelinas R, Maurath G, Cannon H, Moor D, Billington E, Kempinen H, Washington DC (1990) 20555 NRC FIN D 1682. NUREG/CR-5613 RA

5. Anand A, Jain AK (1987) Earthquakes and deformational structures (seismites) in Holocene sediments from the Himalayan-Andaman Arc, India. Tectonophysics 133:105-120

6. Angelier J, Baruah S (2009) Seismotectonics in Northeast India: a stress analysis of focal mechanism solutions of earthquakes and its kinematic implications. Geophys J Int 178:303-326

7. Bapat A, Kulkarni RC, Guha SK (1983) Catalogue of earthquakes in India and neighbourhood: from historical period up to 1979. Indian Society of Earthquake Technology, Roorkee, p 211

8. Baro 0, Kumar A (2017) Seismic source characterization for the Shillong plateau in Northeast India. J Seismol 21:1229-1249

9. Bilham R (2004) Earthquakes in India and the Himalaya: tectonics, geodesy and history. Ann Geophys 47:839-858

10. Binita P, Sharma A (2009) Soft-sediment deformation structures in the Late Quaternary sediments of Ladakh: Evidence for multiple phases of seismic tremors in the North western Himalayan Region. $J$ Asian Earth Sci 34:761-770 
11. Cox RT, Harris JB, Forman SL, Brezina T, Gordon J, Gardner C (2012) Holocene faulting on the Saline River fault zone, Arkansas, along the Alabama-Oklahoma transform. In: Cox RT, Tuttle MP, Boyd OS, Locat J (eds) Recent Advances in North American Paleoseismology and Neotectonics East of the Rockies. Geol Soc Am Spec Paper 493:143-174

12. Cox RT, Lowe C, Hao Y, Mahan SA (2014) Use of small scale liquefaction features to assess paleoseismicity: an example from the Saline River fault zone, Southeast Arkansas, USA. Front Earth Sci 2:1-17

13. Dasgupta AB (1977) Geology of Assam Arakan region. Mining Metall Soc India Q. J: 49 1-54

14. Dasgupta S (2011) http://www.scribd.com/doc/47778343/October-1943-Assam- Earthquake\#scribd

15. Iyengar RN, Sharma D (1998) Historical seismicity of India. DST Report, India

16. Iyengar RN, Sharma D, Siddiqui JM (1999) Earthquake History of India in Medieval Times. Indian J His Sci 34(3):181-237

17. Jayangondaperumal R, Thakur VC (2008) Co-seismic secondary surface fractures on southeastward extension of the rupture zone of the 2005 Kashmir earthquake. Tectonophysics 446:61-76

18. Jayangondaperumal R, Thakur VC, Suresh N (2008) Liquefaction features of the 2005 MuzaffarabadKashmir earthquake and evidence of paleoearthquakes near Jammu Kashmir Himalaya. Curr Sci 95:1071-1076

19. Jayangondaperumal R, Wesnousky SG, Choudhuri BK (2011) Near-surface expression of early to late Holocene displacement along the northeastern Himalayan frontal thrust at Marbang Korong Creek, Arunachal Pradesh, India. Bull Seismol Soc Am 101(6):3060-3066

20. Jayangondaperumal R, Kumahara Y, Thakur VC, Srivastava AKumarP, Shubhanshu D, Joe V, Dubey AK (2017) Great earthquake surface ruptures along back thrust of the Janauri anticline, NW Himalaya. J Asian Earth Sci 133:89-101

21. Jayangondaperumal R (2021) Geological Evidence of Great Earthquakes along the Eastern Himalayan Foothills. J Geol Soc India 97:823-926

22. Kayal JR (2008) Microearthquake Seismology and Seismotectonics of South Asia. McGraw Hill Publication, India

23. Kayal JR, Arefie SS, Barua S, Hazarika D, Gogoi N, Kumar A, Chowdhury SN, Kalita S (2006) Shillong plateau earthquakes in northeast India region: complex tectonic model. Curr Sci 91:109-114

24. Kayal JR, Arefiev SS, Baruah S, Tatevossian R, Gogoi N, Sanoujam M, Gautam JL, Hazarika D, Borah D (2010) The 2009 Bhutan and Assam felt earthquakes (Mw 6.3 and 5.1) at the Kopili fault in the northeast Himalaya region. Geomat Nat Haz Risk 1:273-281

25. Kayal JR, Arefiev SS, Baruah S, Hazarika D, Gogoi N, Gautam JL, Baruah Santanu,Dorbath C, Tatevossian R (2012) Large and great earthquakes in the Shillong plateau-Assam valley area of northeast India region: pop-up and transverse tectonics. Tectonophysics 532-535:186-192

26. Kumar S, Wesnousky SG, Jayangondaperumal R, Nakata T, Kumahara Y, Singh V (2010)

Paleoseismological evidence of surface faulting along the northeastern Himalayan front, India: timing, size, and spatial extent of great earthquakes. J Geophys Res 115:B12422 
27. Kumar D, Reddy DV, Pandey A (2016) Paleoseismic investigations in the Kopili fault zone of North East India: Evidences from liquefaction chronology. Tectonophysics.

https://doi.org/10.1016/j.tecto.2016.02.016

28. Lakshmi BV, Gawali PB (2022) Soft sediment deformation features in Dauki Fault region: Evidence of paleoearthquakes, Shillong Plateau, NE India.Environ Earth Sci81

29. Malik JN, Sahoo S, Satuluri S, Okumura K (2015) Active Fault and paleoseismic studies in Kangra Valley: evidence of surface rupture of a Great Himalayan 1905 Kangra Earthquake (Mw 7.8), Northwest Himalaya India. Bull Seismol Soc Am 105:2325-2342

30. Malik JN, Naik SP, Sahoo S, Okumura K, Mohanty A (2017) Paleoseismic evidence of the CE 1505 (?) and CE 1803 earthquakes from the foothill zone of the Kumaon Himalaya along the Himalayan Frontal Thrust (HFT) India. Tectonophysics 714:133-145

31. Mishra RL, Singh I, Pandey A, Rao PS, Sahoo HK, Jayangondaperumal R (2016) Paleoseismic evidence of a giant medieval earthquake in the eastern Himalaya. Geophys Res Lett 43(11):5707-5715

32. Morino M, Kamal ASMM, Muslim D, Ali RMdE, Kamal MA, Rahman MdZ, Kaneko F (2011) Seismic event of the Dauki Fault in 16th Century confirmed by trench investigation at Gabrakhari Village, Haluaghat, Mymensingh, Bangladesh. J Asian Earth Sci 42:492-498

33. Morino M, Kamal ASMM, Akhter SH, Rahman MdZ, Ali RMdE, Talukder A, Khan MdMH, Matsuo J, Kaneko F (2014) A paleo-seismological study of the Dauki fault at Jaflong, Sylhet, Bangladesh: Historical seismic events and an attempted rupture. J Asian Earth Sci 491:218-226

34. Moretti M, Alfaro P, Caselles O, Canas JA (1999) Modelling seismites with a digital shaking table. Tectonophysics 304(4):369-383

35. Mugnier JL, Huyghe P, Gajurel A, Upreti B, Jouanne F (2011) Seismities in the Kathmandu basin and seismic hazard. Tectonophysics 509:33-49

36. Murray A, Wintle A (2000) Luminescence dating of quartz using an improved single aliquot regenerative-dose protocol. Mater Sci 32:57-73

37. Murthy MVN, Talukdar SC, Batthacharya AC (1969) The Dauki Fault of Assam. Bull Oil Nat Gas Comm 6:57-64

38. Nandy DR (2001) Geodynamics of Northeastern India and the Adjoining Region. ACB Publication, Kolkata, p 209

39. Nandy DR, Dasgupta S (1991) Seismotectonic domains of northeastern India and adjacent areas. Phys Chem Earth 18:371-384

40. Obermeier SF (1996) Use of liquefaction-induced features for paleoseismic analysis: an overview of how seismic liquefaction features can be distinguished from other features and how their regional distribution and properties of source sediment can be used to infer the location and strength of Holocene paleo-earthquakes. Engin Geol 44:1-76

41. Obermeier SF (1998) Liquefaction evidence for strong earthquakes of Holocene and Latest Pleistocene ages in the States of Indiana and Illinois, USA. Engin Geol 50:227-254 
42. Obermeier SF, Pond EC (1999) Issues in using liquefaction features for paleoseismic analysis. Seismol Res Lett 70:34-58

43. Obermeier SF (2009) Using liquefaction-induced and other soft-sediment features for paleoseismic analysis. In: McCalpin, J.P. (ed.), Paleoseismology (2nd edition). Academic Press, London, 497-564

44. Oldham T (1883) The Cachar earthquake of 10th January 1869. Mem Geol Surv. 19:1-88

45. Oldham RD (1899) Report on the great earthquake of 12th June, 1897. Mem Geol Surv India 29:1-379

46. Owen G, Moretti M (2011) Identifying triggers for liquefaction-induced soft-sediment deformation in sands. Sediment Geol 23:141-147

47. Pandey A, Jayangondaperumal R, Hetényi G, Priyanka SR, Singh I, Srivastava P, Srivastava HB (2021) Establishing primary surface rupture evidence and magnitude of the 1697 CE Sadiya earthquake at the Eastern Himalayan Frontal thrust, India. Sci Rep 11(1):1-14

48. Philip G, Suresh N, Bhakuni SS, Gupta V (2011) Paleoseismic investigation along Nalagarh Thrust: Evidence of Late Pleistocene earthquake in Pinjaur Dun, Northwestern sub-Himalaya. J Asian Earth Sci 40:1056-1067

49. Porat N, Levi T, Weinberger R (2007) Possible resetting of quartz OSL signals during earthquakesEvidence from late Pleistocene injection dikes, Dead Sea basin, Israel. Quat Geochronol 2:272-277

50. Priyanka RS, Jayangondaperumal R, Pandey A, Mishra RL, Singh I, Bhushan R et al (2017) Primary surface rupture of the 1950 Tibet-Assam great earthquake along the eastern Himalayan front, India. Sci Rep 7(1):1-12

51. Rajendran CP, Rajendran K, Duarah BP, Baruah S, Earnest A (2004) Interpreting the style of faulting and paleoseismicity associated with the 1897 Shillong, northeast India, earthquake: Implications for regional tectonism. Tectonics 23(4):1-12

52. Rajendran CP, John B, Rajendran K (2015) Medieval pulse of great earthquakes in the central Himalaya: Viewing past activities on the frontal thrust. J Geophys Res Solid Earth 120:1623-1641

53. Rajendran CP (2021) Constraints on previous earthquakes from the liquefaction sites in the Kathmandu Valley associated with the 2015 Gorkha earthquake and their regional implications. Quat Int 585:44-54

54. Reddy DV, Nagabhushanam P, Kumar D, Sukhija BS, Thomas PJ, Pandey AK, Sahoo RN, Ravi Prasad GV, Datta K (2009) The great 1950 Assam Earthquake revisited: Field evidences of liquefaction and search for paleoseismic events. Tectonophysics 474:463-472

55. Russ DP (1982) Style and significance of surface deformation in the vicinity of New Madrid, Missouri. In: McKeown F.A. and Pakiser L.C., eds. Investigations of the New Madrid, Missouri, Earthquake Region. U. S. Geol Survey Prof. Paper 1236:95-114

56. Saucier RT (1989) Evidence for episodic sand-blow activity during the 1811-1812 New Madrid (Missouri) Earthquake Series. Geology 17:103-106

57. Seed HB (1979) Soil liquefaction and cyclic mobility evaluation for level ground duringearthquakes. Proc. Am. Soc. Civil Engin. J Geotech Engin 105:201-255 
58. Sims JD (1973) Earthquake induced structures in sediments of Van Norman Lake, San Fenando, California. Science 182:161-163

59. Sims JD, Garvin CD (1995) Recurrent liquefaction induced by the 1989 Loma Prieta earthquake and 1990 and 1991 aftershocks: implications for paleoseismicity studies. Bull Seism Soc Am 85:51-65

60. Singh S, Jain AK (2007) Liquefaction and fluidization of lacustrine deposits from Lahaul-Spiti and Ladakh Himalaya: geological evidences of palaeoseismicity along active fault zone. Sediment Geol 196:47-57

61. Singh BP, Mondal K, Singh A, Mittal Singh RK, Kanhaiya S (2020) Seismic origin of the soft-sediment deformation structures in the upper Palaeo-Mesoproterozoic Semri Group, Vindhyan Supergroup, Central India. Geol J: 1-15

62. Singh I, Pandey A, Mishra RL, Priyanka RS, Brice A, Jayangondaperumal R, Srivastava V (2021) Evidence of the 1950 great Assam earthquake surface break along the Mishmi Thrust at Namche Barwa Himalayan Syntaxis.Geophys Res Lett48

63. Sukhija BS, Rao MN, Reddy DV, Nagabhushanam P, Hussain S, Chadha RK, Gupta HK (1999) Paleoliquefaction evidence and periodicity of large prehistoric earthquakes in Shillong Plateau, India. Earth Planet Sci Lett 167:269-282

64. Sukhija BS, Rao MN, Reddy DV, Nagabhushanam P, Kumar D, Lakshmi BV, Sharma P (2002) Palaeoliquefaction evidence of prehistoric large/great earthquakes in north Bihar, India. Cur Sci 83:1019-1025

65. Talwani P, Cox J (1985) Paleoseismic evidence for recurrence of earthquakes near Charleston, South Carolina. Science 229:379-381

66. Thomas PJ, Reddy DV, Kumar D, Nagabhushanam P, Sukhija BS, Sahoo RN (2007) Optical dating of liquefaction features to constrain prehistoric earthquakes in Upper Assam, NE India-some preliminary results. Quat Geochronol 2:278-283

67. Tuttle MP, Seeber L (1991) Historic and prehistoric earthquakeinduced liquefaction in Newbury, Massachusetts. Geology 19:594-597

68. Tuttle MP, Shukri HA, Mahdi H (2006) Very large earthquakes centered southwest of the NewMadrid seismic zone 5,000-7,000 years ago. Seism Res Lett 77:664-678

69. Tuttle MP, Atkinson GM (2010) Localization of large earthquakes in the Charlevoix seismic zone, Quebec,Canada, during the past 10,000 years. Seism Res Lett 81:140-147

70. Tuttle MP, Wolf LW, Starr ME, Villamor P, Mayne PW, Lafferty RH III, Morrow JE, Scott RJ Jr, Forman SL, Hess K, Tucker K, Dunahue J, Haynes ML (2019) Evidence for large New Madrid earthquakes about AD 0 and BC 1050, Central United States. Seismol Res Lett 90:1393-1406

71. Youd TL (1973) Liquefaction, flow, and associated ground failure. US Geol Surv Circ 688:1-12

72. Youd TL, Kuribayashi E, Tatsuoka F (1977) 1975, in Soil and Foundations 15, 81-92. Soils Foun 17:82-85

\section{Figures}




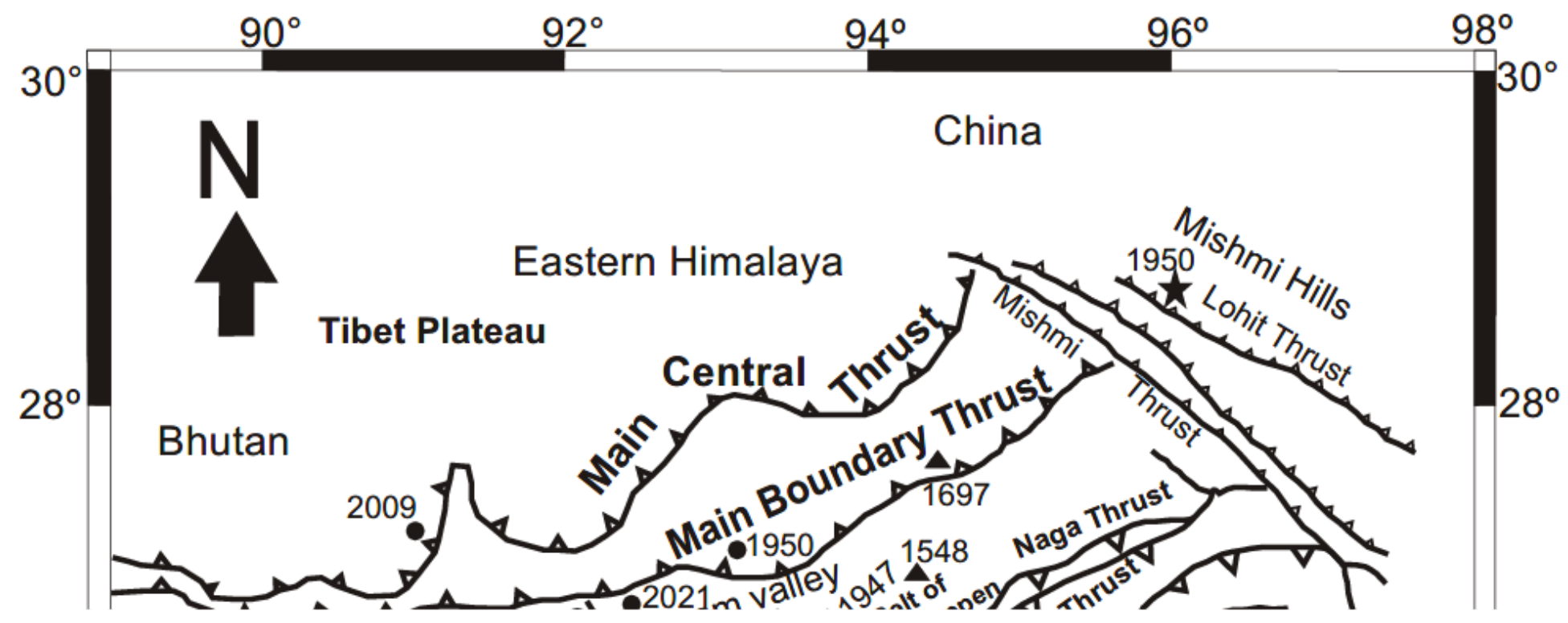

Figure 1

Regional tectonic settings of Northeast India and surrounding regions. CF: Chedrang Fault, OF: Oldham Fault, SF:Samin Fault, DdF: Dhudnoi Fault, DT: Dapsi Thrust, BS: Barapani Shear Zone, BL: Bomdila Fault (Map sources: Murthy et al.1969; Nandy 2001; Angelier and Baruah 2009). Non-instrumental (Source: lyengar et al., 1999) and instrumental earthquakes of magnitude $\geq 6$ are plotted on the map (Sources: USGS and NCS, India). Black star depicts the two great earthquakes 1897 (Mw-8.1) and 1950 (Mw-8.3) that are occurred in the region 


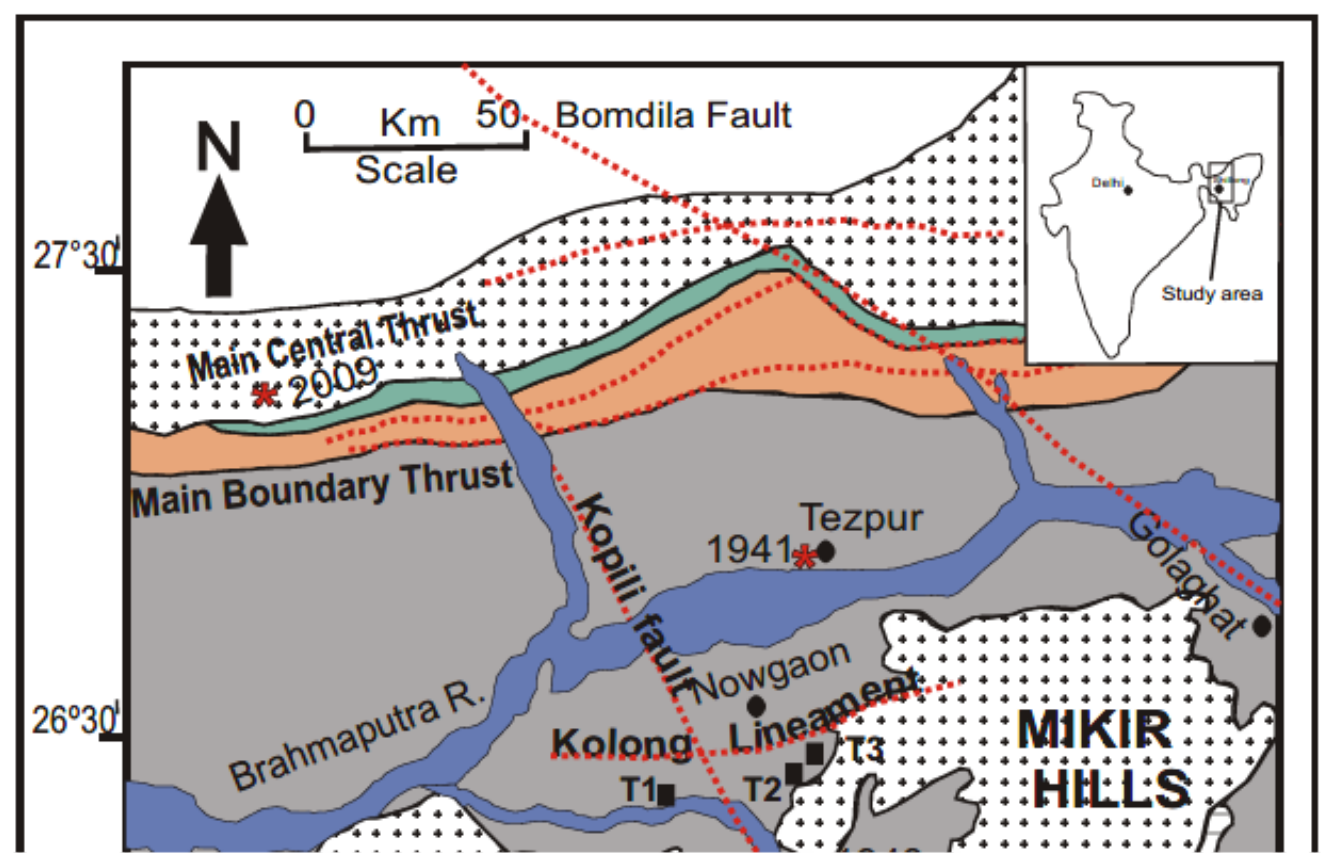

\section{Figure 2}

(a) Geological location map of the study trench sites along Kolong River, showing major structures (modified after Dasgupta, 1977 and Nandy, 2001). T1-Trench 1 at Namgaon site, T2-Trench 2 at Nampani site and T3-Trench 3 at Satargaon site. Epicentres of earthquakes that occurred in the Kopili fault region are plotted on the map 


\section{Figure 3}

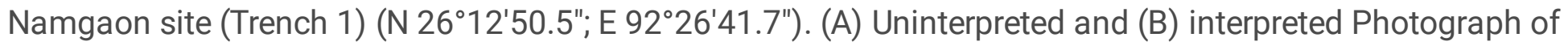
multiple sand dykes (D1,D2,D3,D4 and D5) and related sand blow in a 1.8 $\mathrm{m}$ long and $2 \mathrm{~m}$ deep trench 1 section. (B) Two generation of main dykes D1 and D2 may be originating from the same source and D3 \& D4 branched from D1 dyke. There is a second generation of sand dyke D2 crosscuts the older D3 dyke. The stratigraphic position and crosscutting relation of D3 dyke shows that it is older than D2 dyke and clearly indicates their formation in two distinct events which might have occurred within a short period of time. Another sand dyke D5 is terminated at $98 \mathrm{~cm}$ and no source sand layer observed. OSL date of AD 16921770 denotes the contemporaneous age for the older event, AD 1782-1826 provides maximum age for $D 2$, D3 and D4 dykes and AD 1848-1885 provides maximum age for D2 dyke. From its stratigraphic position and OSL age data within the section, the $\mathrm{D} 2$ dyke probably resulted from the $\sim 1869$ earthquake. Lithology of trench section consists of Unit 1: massive clay, Unit 2: clay-silt of light grey-brownish color and Unit 3: Grey color silt/clay

\section{Figure 4}

Nampani site (Trench 2) ( $\left.\mathrm{N} 26^{\circ} 21^{\prime} 58^{\prime \prime} ; \mathrm{E} 92^{\circ} 46^{\prime} 38.7^{\prime \prime}\right)$. Locations of $5 \mathrm{~B}, \mathrm{C}$ and $\mathrm{D}$ are shown on $5 \mathrm{~A}$ and $5 \mathrm{C}$ on 5B. (A) Photograph of $\sim 3 \mathrm{~m}$ long and $2 \mathrm{~m}$ deep Trench 2 showing three generations of sand blows and related sand dykes. Age constraints were developed on the basis of OSL date within sand blow 1 yielded age of AD 1889-1915 (115 \pm 13$)$. Lithology of trench section consists of Unit 1: clay, Unit 2: sand blow 1, Unit 3: brown silt, Unit 4: sand blow 2, Unit 5: sticky clay, Unit 6: sand blow 3 and Unit 7: sticky clay. (B) Mosaic photograph details showing a youngest sand blow 1 consists of white fine sand. (C) Photograph details showing sand blow 2 (Unit 4), sand blow 3 (Unit 6) and related sand dyke. Sand blow 2 is of limited lateral

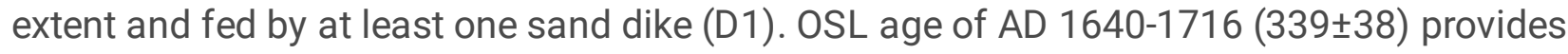
contemporaneous age on triggering paleoearthquake. (D) Photograph showing oldest sand blow 3 and related sand dykes 1 and 2. OSL age AD 1540-1626 (434 \pm 43$)$ of sample from this unit 6 provides contemporaneous age for the paleoearthquake that caused the liquefaction feature

\section{Figure 5}

Satargaon site (Trench 3) (N 26 $\left.23^{\prime} 12.5^{\prime \prime} ; \mathrm{E} 92^{\circ} 47^{\prime} 43.1\right)$. (A) Uninterpreted and (B) interpreted photograph of $2 \mathrm{~m}$ long and $1.2 \mathrm{~m}$ deep trench section showing sand blow 1 (SB1), sand blow 2 (SB2), sand dyke and 
flame like intrusion features. SB2 (Unit 5) is $~ 10 \mathrm{~cm}$ thick and SB1 is $25 \mathrm{~cm}$ thick and composed of fine silt and brown sand. One main sand dyke, $5 \mathrm{~cm}$ wide, fed the SB1. The dyke composed of fine light yellow sand, crosscutting unit 6 and terminated in Unit 5 (SB2). Flame like intrusion of clay deposit is also observed (Unit 4) and clasts of clay in the sand blow. Sample collected from within the sand blow 1 yielded OSL date of AD 1057-1211 (883 \pm 77 ) provides contemporaneous age constraint for the event. Lithology of trench section consists of Unit 1: clay, Unit 2: silt, Unit 3: brown silt-sand, Unit 4: clay, Unit 5: fine sand and Unit 6: silt-clay

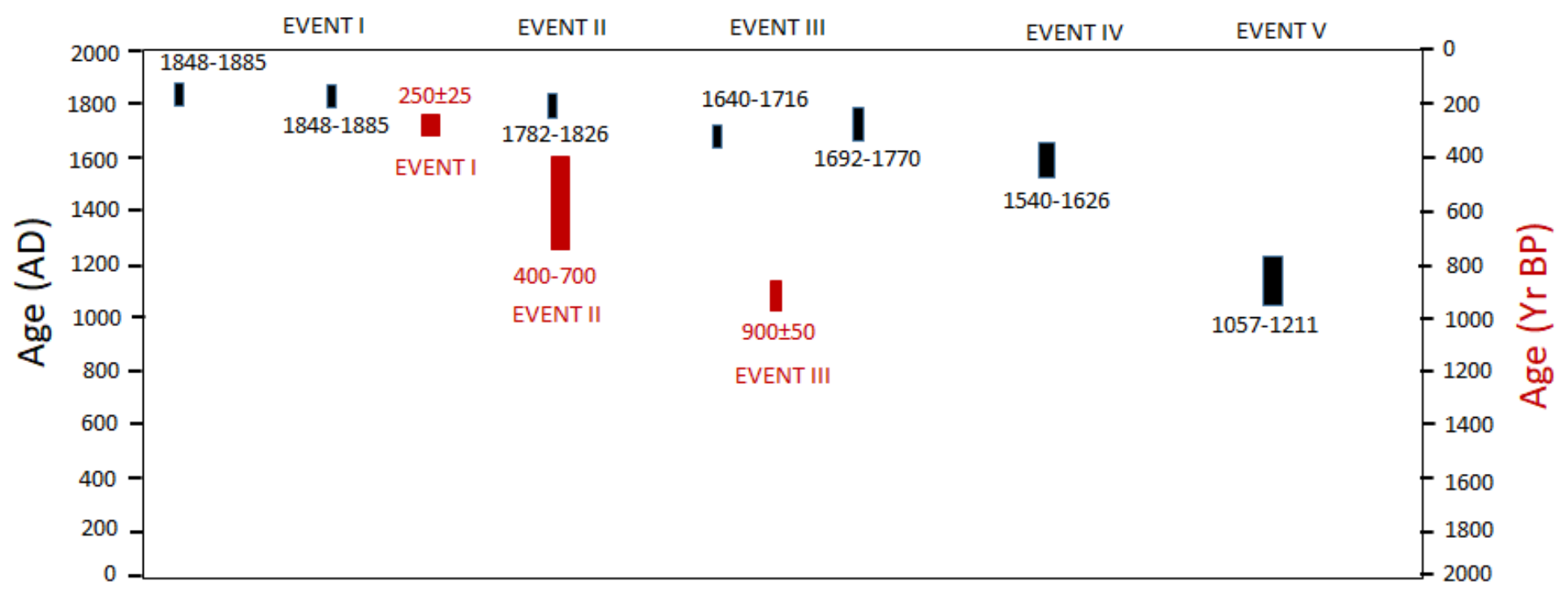

\section{Figure 6}

The occurrence of earthquakes depicted in trench sediments in Kopili region, is stacked up for possible correlation of events. Kumar et al. (2016) dated events are compared with our findings and there is some consonance with the events. Black and red thick bar ones are present and previous (Kumar et al. 2016) findings of paleoearthquakes in the Kopili fault region 